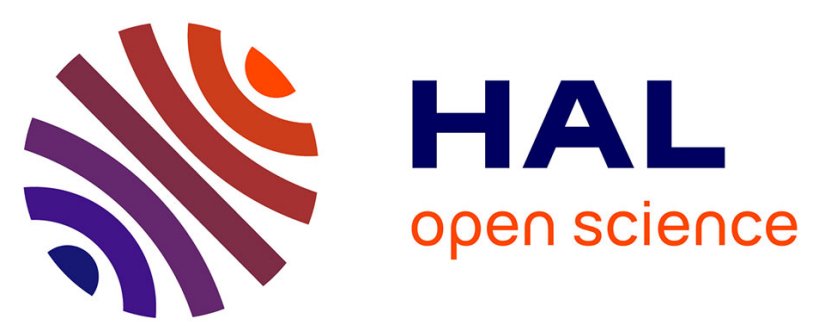

\title{
Evaluation of Timber and Carbon Sequestration Income of Cunninghamia Lanceolata Timber Forest and Management Decision Support
}

Yan Qi, Baoguo Wu, Shanghong Li

\section{- To cite this version:}

Yan Qi, Baoguo Wu, Shanghong Li. Evaluation of Timber and Carbon Sequestration Income of Cunninghamia Lanceolata Timber Forest and Management Decision Support. 9th International Conference on Computer and Computing Technologies in Agriculture (CCTA), Sep 2015, Beijing, China. pp.530-538, 10.1007/978-3-319-48354-2_54 . hal-01614204

\author{
HAL Id: hal-01614204 \\ https://hal.inria.fr/hal-01614204
}

Submitted on 10 Oct 2017

HAL is a multi-disciplinary open access archive for the deposit and dissemination of scientific research documents, whether they are published or not. The documents may come from teaching and research institutions in France or abroad, or from public or private research centers.
L'archive ouverte pluridisciplinaire HAL, est destinée au dépôt et à la diffusion de documents scientifiques de niveau recherche, publiés ou non, émanant des établissements d'enseignement et de recherche français ou étrangers, des laboratoires publics ou privés.

\section{(c)(1)}

Distributed under a Creative Commons Attribution| 4.0 International License 


\title{
Evaluation of Timber and Carbon Sequestration Income of Cunninghamia Lanceolata Timber Forest and Management Decision Support
}

\author{
Yan $\mathrm{Qi}^{1}$ Baoguo $\mathrm{Wu}^{2}$ Shanghong $\mathrm{Li}^{1 *}$ \\ 1 International College Beijing, China Agricultural University, Beijing, China \\ meganqiyan@sina.cn, shanghongli@cau.edu.cn \\ 2 Beijing Forestry University, Beijing 100083, China \\ wubg@bjfu.edu.cn
}

\begin{abstract}
Carbon sequestration exchange has just started in China. This study was based on the general plantation regions in Fujian China where Cunninghamia lanceolata is quite popular and has great economic and ecological significance for farmers and the society at large. This study used Hartman model to forecast the income of timber sales and carbon sequestration so as to integrate the model in the decision support system to find a practical tool for farmers to project their future monetary income to make sound operating decisions in terms of plantation density and rotation age, which is of practical significance and innovation.
\end{abstract}

Key words: Evaluation, timber income, carbon sequestration income, Cunninghamia lanceolata, management decision support

\section{Introduction}

Facing the huge social demand for industrial forest products, as well as the serious challenge of the environmental protection put forward by the global climate warming, the sustainable management of artificial timber forest has the important dual role of economic benefits creation and environmental protection. The foreign countries advanced in forestry have achieved the $60 \%$ - 93\% of the total industrial forest products by using the artificial timber forest which takes only $1.2 \%-16 \%$ of their total forest area, ${ }^{[1]}$ which poses a challenge to China and at the same time provides very good experiences too.

The Cunninghamia lanceolata (China fir) is one of the unique fast-growing commercial timber tree species. It has fast growth speed, good timber material of being light and toughening at the same time, moderate intensity, and high quality. It is fragrant, resistant to insect decay and easy to process. Its broad economic use can be found in construction, furniture, appliances, shipbuilding, etc. The Cunninghamia lanceolata is widely planted in the 16 provinces and regions in south China. It is the one of the important forest resources in south China as one of the most important afforestation and fast-growing timber tree species in southern collective forest region of China. And it is the most widespread plantation and ecological system in Fujian province.

The Chinese fir plantation has great ecological, economic and social benefits. Therefore, it is of great significance to study on the sustainable management of the Chinese fir artificial timber forest.

\section{Literature Review}

${ }^{*}$ International College Beijing, China Agricultural University, Beijing, China 
With the background of global climate change and environmental protection, research on carbon sequestration has drawn a lot of attention in the academic field, including the carbon sequestration related research about Cunninghamia lanceolata. Bayer et al highlighted the importance of forest biomes for maintaining and increasing biogeochemical carbon sequestration in their study, considering the biome-specific response to current climate and land use, and their projections for the future ${ }^{[2]}$.

Huang et al analyzed the carbon sequestration in living biomass and soil organic carbon pools using the carbon estimation model and reached the amount of carbon stock up to date and in both the past and the future. According to them, from 1950 to 2012, plantations in China sequestered $1.686 \mathrm{Pg}$ carbon by net uptake into biomass and emissions of soil organic carbon. The carbon stock of China's present plantations was $7.894 \mathrm{Pg}, 21.4 \%$ as forest biomass and $78.6 \%$ as soil organic carbon. They projected that China's carbon stock will reach a level of $3.169 \mathrm{Pg}$ by 2050 , and it will amount to $10.395 \mathrm{Pg}^{[3]}$

There have been some comparison studies. Yen and Lee conducted a comparison study on the aboveground carbon sequestration between moso bamboo (Phyllostachys heterocycla) and Chinese fir (Cunninghamia lanceolata) forests based on the allometric model. ${ }^{[4]}$ NIU et al conducted a comparison study on the carbon storages in Cunninghamia lanceolata and Michelia macclurei plantations during a 22-year period in south China ${ }^{[5]}$.

Chen et al investigated changes of carbon stocks in Cunninghamia lanceolata plantations converted from a natural broadleaved forest, based on a typical chronosequence in mountain land of subtropical China, which includes six first- generation Chinese fir stands at different development stages. It was concluded that over-mature tree plantations had a limited role in continuously sequestering carbon, and that the soil organic pools of tree plantations can be hardly recovered to those of natural forests due to a large initial loss and a low late gain in soil organic carbon following tree plantation establishment. ${ }^{[6]}$

The research on management of timber forest is of more significance to this study. In Wang et al's study, field data were combined with the forest ecosystem management model FORECAST to estimate the impacts of different forest management strategies, that is, the choice of different combinations of planting densities, rotation lengths, and different harvesting intensities, on carbon sequestration of Phoebe bournei plantations in south-eastern China ${ }^{[7]}$.

From Noormets et al's study, it is amazing to find that managed forests generate about $50 \%$ lower carbon stocks than unmanaged forests. It was found the same with the gross primary productivity (GPP) and total net primary productivity (NPP), but relatively more of the assimilated carbon is allocated to aboveground pools in managed than in unmanaged forests, whereas allocation to fine roots and rhizosymbionts is lower. ${ }^{[8]}$ Therefore, a good management strategy should be able to balance the benefits of timber sales and carbon sequestration for the long-term sustainability.

\section{Materials and Methods}

The Hartman model was proposed by Richard Hartman in the middle of the 1970s. He introduced the amenity service function of forests to the Fautsmann model so as to combine the assessment of economic income with the ecological income of forests. The Hartman Model is an objective function equation taking a rotation period as the variable rendering a rotation age at which the integrated income can be maximized. ${ }^{[9][10]}$ 


$$
\max _{T \geq T^{0}} \quad L E V(T)=\frac{1}{1-e^{-r T}}\left[-C+\int_{t=1}^{T} f(t) e^{-r t} d t+p(T) V(T) e^{-r T}\right]
$$

where,

$T=$ rotation age

$R=$ discount rate

$C=$ regeneration cost

$p(T)=$ stumpage price at age $T\left(\right.$ Yuan $\left./ \mathrm{m}^{3}\right)$

$V(T)=$ growing stock of timber at age $T\left(\mathrm{~m}^{3} / \mathrm{mu}\right)$

$p(T) V(T)=$ the economic income of timber

$f(t)=$ function of amenity or ecological income

By calculating land expected values (LEV) at different rotation ages, a maximized expected value can be reached. In the meantime, the rotation age when LEV can be maximized can be found. This is helpful for reaching the reasonable management strategy.

Including the income of carbon sequestration in the Hartman model, the model looks like: ${ }^{[9]}$

$$
\max _{T} L E V(T)=\frac{-C+\sum_{t=0}^{T} p_{c} g(t) e^{-r t}+P(T) V(T) e^{-r T}-e^{-r T} \sum_{t=0}^{d} p_{c} V(T) q(t) e^{-r t}}{1-e^{-r T}}
$$

Where,

$C=$ regeneration cost (Yuan/mu)

$p(T)=$ stumpage price at age $T\left(\right.$ Yuan $\left./ \mathrm{m}^{3}\right)$

$p_{c}=$ social benefits of carbon sequestration $\left(\right.$ Yuan $/ \mathrm{m}^{3}$ )

$r=$ discount rate

$V(T)=$ growing stock of timber at age $T\left(\mathrm{~m}^{3} / \mathrm{mu}\right)$

$g(t)=$ timber growth at age $t\left(\mathrm{~m}^{3} / \mathrm{mu} /\right.$ year $)$

$q(t)=$ rate of decay of harvested timber at time $t(\%)$

$d=$ time period during which the harvested timber completely decays

Before reaching the yield of carbon sequestration, the general biomass of forests should be calculated based on the volume of timber.

Following that, the carbon sequestration reserves can be calculated according to the total biomass volume. Usually the calculation is based on the proportion of carbon storage in the dry weight of plant organics. The international practice is to adopt the rate of 0.50 , thus total carbon sequestration reserves $=$ total biomass ${ }^{*} 0.5 .{ }^{[11]}$

The monetary income of carbon sequestration then can be calculated finally. According to the first transaction practice of farmers' carbon sequestration exchange in China in 2014, 42 farmers 
sold 4,285 tons of carbon sequestration for the monetary income of 128,550 yuan in total. Thus in this study, the price of forest carbon sequestration was set as 30 yuan/ton. ${ }^{[12]}$ And in this paper, the parameter $d$ was set to 1 .

The economic parameters have been reached by visiting farmers and markets in the general plantation regions in Fujian.

i. According to the investigations on the forest land and mountain land in general regions, the land rent of the medium level is selected, that is, the opportunity cost of land use is 122.45 yuan/mu/year. In other words, the farmer would have a rental income of 122.45 yuan/mu/year if he or she let this land out to others.

ii. Renminbi benchmark interest rates of loans by the financial institutions in China are as follows.

Annual rate \%

\begin{tabular}{l|l} 
Item & Since June 28, 2015 \\
\hline Interest rates of loans & \multicolumn{2}{|l}{} \\
\hline Short-term loans & 4.85 \\
\hline Within 1 year (including 1 year) & \\
\hline Mid/Long-term loans & 5.25 \\
\hline 1 to 5 years (including 5 years) & 5.40 \\
\hline Above 5 years &
\end{tabular}

Considering the assumption of continuous operation and land management, where farmers contract the land and land use rights and may extend the contract after the expiration of the original contract, so this study adopted mid/long-term interest rates of $5.40 \%$ as the expected rate of return.

iii. The initial plantation density is found at 3 levels based on the practice of the general regions of plantation in Fujian, 133 plants/mu at the lowest level, 267 plants/mu at the medium level and 400 plants/mu at the highest level.

iv. Afforestation cost: Seedling cost of 0.20 yuan/plant (20-50 CM of height, $0.3 \mathrm{CM}$ of ground diameter); soil preparation, plantation, machinery and utility costs of 380 yuan/mu; Total afforestation costs at 3 levels of initial plantation desinty are 406.60 yuan/mu, 433.40 yuan/mu and 460 yuan/mu.

v. Cost of forest culture and management: nurture and protection cost 40 yuan/mu/year averagely during the different stages of growth of the timber forest; cost of fertilization and pest control is 100 yuan/mu/year averagely.

vi. Commercial timber price of Cunninghamia lanceolata is 900 yuan $/ \mathrm{m}^{3}$

vii. Trees growth model and the natural growth process table This study adopted the tree growth model and table of volume given by Zongming He et al, where were based on the large amounts of data and information of 665 fixed and temporary HWWCCSC standard plantation plots of the general regions of Cunninghamia 
lanceolata in Fujian province. They established the natural growth model and the natural growth process table of Chinese fir timber forest in Fujian general plantation regions. This study used the natural growth process table based on the status index 16 to reach the Chinese fir artificial timber forest tree volume, which laid the foundation for further calculation of the commercial timber income and carbon sequestration income. ${ }^{[13]}$

viii. To convert the tree volume of Cunninghamia lanceolata to the general biomass of forests, this study adopted the following function: ${ }^{[14]}$

$$
B=12.82556+0.4621618 \mathrm{~V}
$$

Where, $\mathrm{B}$ represents the general biomass,

$\checkmark$ represents the tree volume

\section{$4 \quad$ Findings and analysis}

Using the Hartman model, both the expected timber income and expected carbon sequestration of the general plantation regions of Cunninghamia lanceolata timber forests in Fujian at three different levels of plantation density were found respectively. And more importantly, the highest land expected values of the Cunninghamia lanceolata timber forests and the corresponding ages to reach the land expected values were found at the same time.

From Table 1, at the plantation density of 133 plants/mu, the highest land expected value including the expected value of both timber income and carbon sequestration income can be reached at the forest age of 20 at 3,020.13 yuan/mu. It was also found that the highest expected value of timber income would be reached in the same year as the land expected value at year 20. At year 20, the expected value of the timber income is $2,262.63 \mathrm{yuan} / \mathrm{mu}$, and expected value of the accumulated carbon sequestration of 757.50 yuan/mu.

Table 1. Land Expected Value (LEV) of Cunninghamia lanceolata in general plantation regions of Fujian at the density of 133 plants/mu

\begin{tabular}{ccccccccc}
\hline Age & $\begin{array}{c}\text { Tree } \\
\text { volume } \\
\text { (year) }\end{array}$ & $\begin{array}{c}\text { NPV of } \\
\text { accumulated } \\
\text { annual cost } \\
\text { (yuan/mu) }\end{array}$ & $\begin{array}{c}\text { NPV of } \\
\text { accumulated } \\
\text { carbon } \\
\text { sequestrati } \\
\text { on (yuan/mu) }\end{array}$ & $\begin{array}{c}\text { NPV of } \\
\text { timber } \\
\text { income } \\
\text { (yuan/mu) }\end{array}$ & $\begin{array}{c}\text { EV of } \\
\text { timber } \\
\text { income } \\
\text { (yuan/mu) }\end{array}$ & $\begin{array}{c}\text { EV of } \\
\text { accumulated } \\
\text { carbon } \\
\text { sequestration } \\
\text { (yuan/mu) }\end{array}$ & $\begin{array}{c}\text { LEV } \\
\text { (yuan/mu) }\end{array}$ & $\begin{array}{c}\text { Discounting } \\
\text { factor }\end{array}$ \\
\hline 5 & 0.728000 & 1119.25 & 150.71 & -1025.68 & -4334.71 & 95.26 & -4239.45 & 0.763379 \\
10 & 4.516667 & 1973.66 & 278.13 & -11.39 & -27.29 & 400.88 & 373.59 & 0.582748 \\
15 & 10.275333 & 2625.90 & 381.47 & 1081.46 & 1948.08 & 507.51 & 2455.59 & 0.444858 \\
20 & 16.440000 & 3123.81 & 588.74 & 1494.25 & $\mathbf{2 2 6 2 . 6 3}$ & $\mathbf{7 5 7 . 5 0}$ & $\mathbf{3 0 2 0 . 1 3}$ & 0.339596 \\
25 & 22.054667 & 3503.90 & 752.04 & 1235.21 & 1667.50 & 912.47 & 2579.96 & 0.259240 \\
30 & 26.805333 & 3794.05 & 1003.89 & 573.61 & 715.14 & 1172.22 & 1887.36 & 0.197899 \\
35 & 30.735333 & 4015.55 & 1200.38 & -243.23 & -286.52 & 1352.63 & 1066.12 & 0.151072 \\
\hline
\end{tabular}

From Table 2, at the plantation density of 267 plants/mu, the highest land expected value including the expected value of both timber income and carbon sequestration income can be reached at the forest age of 15 at 4,373.85 yuan/mu, different from that at the density level of 
133 plants/mu. The highest expected value of timber income would be reached, again, in the same year as the land expected value at this density level. And at year 15, the expected value of the timber income is $3,859.08$ yuan/mu, and expected value of the accumulated carbon sequestration of $514.77 \mathrm{yuan} / \mathrm{mu}$.

Table 2. Land Expected Value (LEV) of Cunninghamia lanceolata in general plantation regions of Fujian at the density of 267 plants/mu

\begin{tabular}{ccccccccc}
\hline Age & $\begin{array}{c}\text { Tree } \\
\text { volume } \\
\left(\mathrm{m}^{3} / \mathrm{mu}\right)\end{array}$ & $\begin{array}{c}\text { NPV of } \\
\text { accumulated } \\
\text { annual cost } \\
\text { (yuan/mu) }\end{array}$ & $\begin{array}{c}\text { NPV of } \\
\text { accumulated } \\
\text { carbon } \\
\text { sequestrati } \\
\text { on (yuan/mu) }\end{array}$ & $\begin{array}{c}\text { NPV of } \\
\text { timber } \\
\text { income } \\
\text { (yuan/mu) }\end{array}$ & $\begin{array}{c}\text { EV of } \\
\text { timber } \\
\text { income } \\
\text { (yuan/mu) }\end{array}$ & $\begin{array}{c}\text { EV of } \\
\text { accumulated } \\
\text { carbon } \\
\text { sequestration } \\
\text { (yuan/mu) }\end{array}$ & $\begin{array}{c}\text { LEV } \\
\text { (yuan/mu) }\end{array}$ & $\begin{array}{c}\text { Discounting } \\
\text { factor }\end{array}$ \\
\hline 5 & 1.227333 & 1119.25 & 153.36 & -709.42 & -2998.13 & 96.93 & -2901.20 & 0.763379 \\
10 & 6.769333 & 1973.66 & 287.86 & 1143.28 & 2740.01 & 405.64 & 3145.66 & 0.582748 \\
15 & 12.992000 & 2625.90 & 392.63 & 2142.34 & $\mathbf{3 8 5 9 . 0 8}$ & $\mathbf{5 1 4 . 7 7}$ & $\mathbf{4 3 7 3 . 8 5}$ & 0.444858 \\
20 & 18.244667 & 3123.81 & 604.83 & 2019.02 & 3057.25 & 776.40 & 3833.65 & 0.339596 \\
25 & 22.392667 & 3503.90 & 766.93 & 1287.27 & 1737.78 & 931.87 & 2669.65 & 0.259240 \\
30 & 25.606667 & 3794.05 & 1021.61 & 333.32 & 415.56 & 1196.05 & 1611.61 & 0.197899 \\
35 & 28.094667 & 4015.55 & 1215.38 & -629.07 & -741.02 & 1373.08 & 632.06 & 0.151072 \\
\hline
\end{tabular}

From Table 3, at the plantation density of 400 plants/mu, the highest land expected value including the expected value of both timber income and carbon sequestration income can be reached at the forest age of 15 at 4,402.07 yuan/mu. Again, the highest expected value of timber income is reached in the same year as the land expected value. And at year 15, the expected value of the timber income is $3,885.21 \mathrm{yuan} / \mathrm{mu}$, and expected value of the accumulated carbon sequestration of 516.87 yuan/mu.

Table3. Land Expected Value (LEV) of Cunninghamia lanceolata in general plantation regions of Fujian at the density of 400 plants/mu

\begin{tabular}{rrrrrrrrr}
\hline $\begin{array}{c}\text { Age } \\
\text { (year) }\end{array}$ & $\begin{array}{c}\text { Tree } \\
\text { volume } \\
\left(\mathrm{m}^{3} / \mathrm{mu}\right)\end{array}$ & $\begin{array}{c}\text { NPV of } \\
\text { accumulated } \\
\text { annual cost } \\
\text { (yuan/mu) }\end{array}$ & $\begin{array}{c}\text { NPV of } \\
\text { accumulate } \\
\text { carbon } \\
\text { sequestration } \\
\text { (yuan/mu) }\end{array}$ & $\begin{array}{c}\text { NPV of } \\
\text { timber } \\
\text { income } \\
\text { (yuan/mu) }\end{array}$ & $\begin{array}{c}\text { EV of } \\
\text { timber } \\
\text { income } \\
\text { (yuan/mu) }\end{array}$ & $\begin{array}{c}\text { EV of } \\
\text { accumulate } \\
\text { carbon } \\
\text { sequestration } \\
\text { (yuan/mu) }\end{array}$ & $\begin{array}{c}\text { LEV } \\
\text { (yuan/m }\end{array}$ & $\begin{array}{c}\text { Discounting } \\
\text { factor }\end{array}$ \\
\hline 5 & 1.620000 & 1119.25 & 155.43 & -466.24 & -1970.42 & 98.24 & -1872.17 & 0.763379 \\
10 & 7.420667 & 1973.66 & 290.98 & 1458.28 & 3494.97 & 407.77 & 3902.74 & 0.582748 \\
15 & 13.094667 & 2625.90 & 394.06 & 2156.84 & $\mathbf{3 8 8 5 . 2 1}$ & $\mathbf{5 1 6 . 8 7}$ & $\mathbf{4 4 0 2 . 0 7}$ & 0.444858 \\
20 & 17.748000 & 3123.81 & 605.89 & 1840.62 & 2787.11 & 779.52 & 3566.63 & 0.339596 \\
25 & 21.333333 & 3503.90 & 765.29 & 1013.51 & 1368.21 & 931.84 & 2300.05 & 0.259240
\end{tabular}


Figure 1 shows the different levels of land expected values of the timber forests at different ages and different density levels. As shown in Chart 1, it is obvious that the highest land expected value is generated at the plantation density level of 400 plants/mu. Again the highest expected value of timber income and carbon sequestration income can be found with the plantation density of 400 plants/mu.

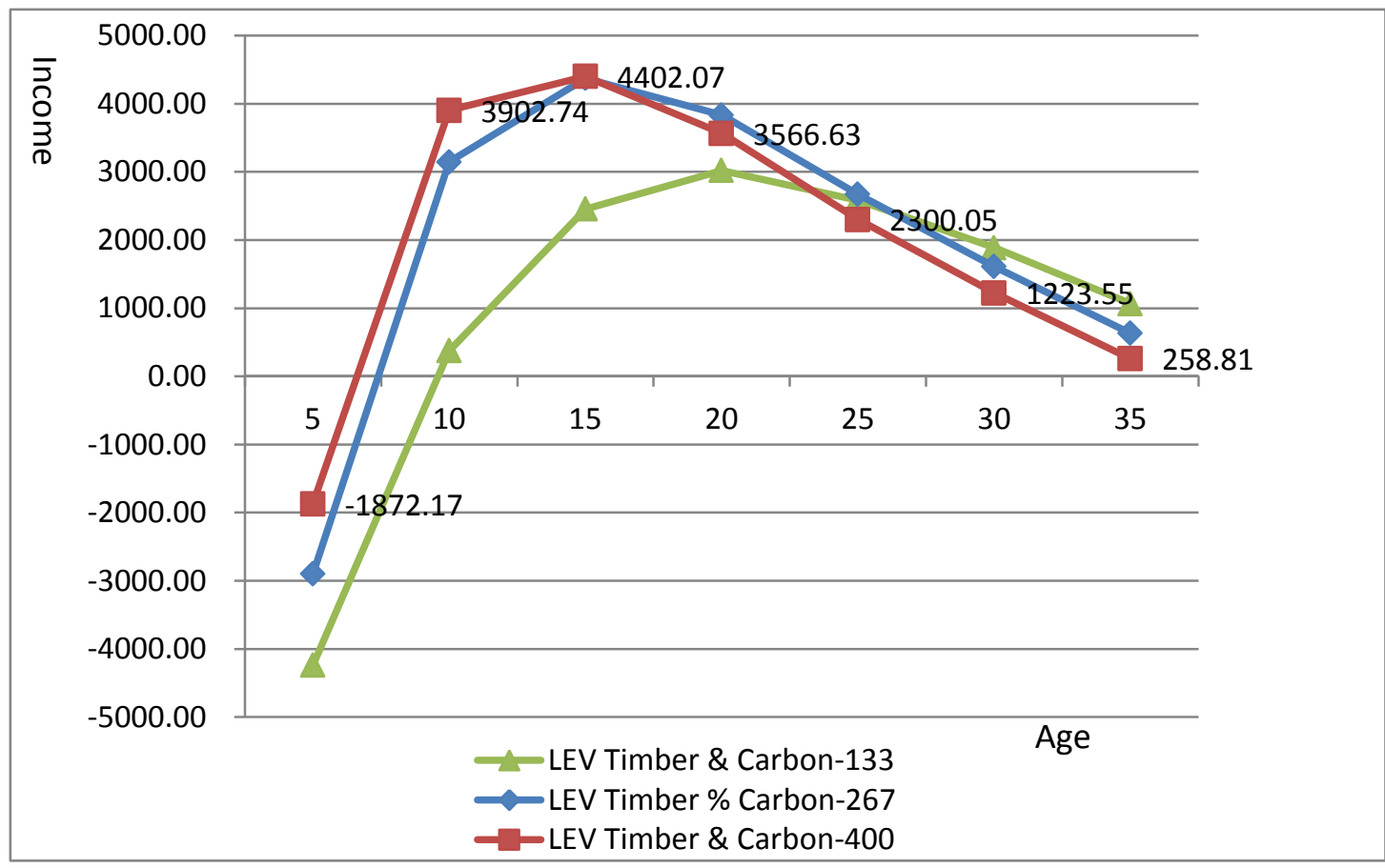

Fig. 1. Comparison of Land Expected Values at different plantation density levels

\section{Conclusion}

Using Hartman model to calculate and forecast the land expected value of the Cunninghamia lanceolata timber forests is effective and important in identifying the ecological income of the forest operations. By doing this, the age of forests when the different levels of timber income and carbon sequestration income can be realized will be able to be found too. All the above proves the validity and usefulness of the Hartman model as the tool of the Cunninghamia lanceolata timber forests' income prediction.

This evaluation model will be integrated in the decision support system to assist farmers' operating decision making. Based on the evaluation and forecast results, the farmers are able to have an estimate of their future income under different operation schemes, that is, at different plantation densities and the arrangement of rotation, etc. And this is exactly the purpose of this study, that is, to apply this evaluation and forecast module in the decision support system so as to find a practical tool for the farmers to assist their decision making.

To conclude, China is expecting a complete national carbon sequestration exchange system, including the market system and the carbon emission quota allocation system, etc. Both theoretically and practically, carbon sequestration income is an important component of the integrated income of farmers of Cunninghamia lanceolata timber forests. It is important to educate the farmers to know about the ecological and economic value of carbon sequestration, 
and more importantly, to know well how to improve this part of income with the aid of related techniques.

\section{References}

[1] Zhou, T. The sustainable operation of artificial forests in China (in Chinese) [D]. The Chinese academy of forestry science. 2008.

[2] Bayer, A. D., Pugh, T. A.M. Krause, A. et al. Historical and future quantification of terrestrial carbon sequestration from a Greenhouse-Gas-Value perspective[J]. Global Environmental Change, 2015, 32,:153-164.

[3 ]Huang, L., Liu, J.Y., Shao, Q.Q., Xu, X.L. Carbon sequestration by forestation across China: Past, present, and future[J]. Renewable and Sustainable Energy Review, 2012, 16(2):1291-1299.

[4] Yen,T.M., Lee, J.S. Comparing aboveground carbon sequestration between moso bamboo (Phyllostachys heterocycla) and China fir (Cunninghamia lanceolata) forests based on the allometric model[J]. Forest Ecology and Management, 2011, 261(6): 995-1002.

[5] Niu D., Wang, S.L., Ouyang Z.Y. Comparisons of carbon storages in Cunninghamia lanceolata and Michelia macclurei plantations during a 22-year period in southern China[J]. Journal of Environmental Sciences, 2009, 21(6): 801-805.

[6] Chen, G.S., Yang, Z.J., Gao, R., Xie, J.S. et al. Carbon storage in a chronosequence of Chinese fir plantations in southern China[J]. Forest Ecology and Management, 2013, 300,:68-76.

[7] Wang, W.F., Wei, X.H., Liao W.M., et al. Evaluation of the effects of forest management strategies on carbon sequestration in evergreen broad-leaved (Phoebe bournei ) plantation forests using FORECAST ecosystem model[J]. Forest Ecology and Management. 2013, 300,:21-32.

[8] Noormets,A.,. Epron, D., Domec, J.C. et al. Effects of forest management on productivity and carbon sequestration: A review and hypothesis[J]. Forest Ecology and Management, 2015, In Press, Corrected Proof, Available online 26 June.

[9] Amacher, G. S., Ollikainen, M., Koskela, E. A. Economics of Forest Resources [M]. Cambridge: The MIT Press. 2009.

[10] Qi, Y., Wu, B.G. The application of the Hartman Model in the assessment of agro-forestry operations' income [J]. Sensor Letters, 2012, 10(1-2):660-665.

[11 ]Xu, T. The estimating technology of forest biomass and carbon storage based on RS information(in Chinese) [J].Forest Inventory and Planning, 2008, 33(3):11-13.

[12] $\mathrm{Xu}, \mathrm{J} .4,000$ tons for 120 thousand RMB: the first successful transaction of carbon sequestration of farmers' forest management (in Chinese)[EB/OL]. http://www.nbd.com.cn/articles/2014-10-16/869259.html, 2014-10-16/2015-03-07.

[13] He, Z.M., Lin, S.Z., Yu, X.T.et al. Study on natural growth model of Chinese fir plantation in ordinary growing area of Fujian (in Chinese)[J]. Journal of Fujian College of Forestry,1997,17(3):231-234.

[14] Wen, Y.G., Qin, W.M., Wei, S.Z. The tentative trial of using tree volume to estimate forest biomass (in Chinese)[J].Forest Science and Technology,1989,7:7-10.

Acknowledgements. This work was supported by National Natural Science Funds of China: Research on the Management Scheme Optimization Decision Model of Cunninghamia Lanceolata Timber Forest under grant [No. 31170513]. 